\title{
A prospective study of role of doppler in pregnancy and the perinatal outcome
}

\author{
Chaithra M., Anitha G. S.*, Sukanya Suresh, Savitha C.
}

Department of Obstetrics and Gynecology, Bangalore Medical College and Research Institute, Bangalore, Karnataka, India

Received: 27 November 2019

Revised: 27 December 2019

Accepted: 31 December 2019

*Correspondence:

Dr. Anitha G. S.,

E-mail: aninaik85@gmail.com

Copyright: () the author(s), publisher and licensee Medip Academy. This is an open-access article distributed under the terms of the Creative Commons Attribution Non-Commercial License, which permits unrestricted non-commercial use, distribution, and reproduction in any medium, provided the original work is properly cited.

\section{ABSTRACT}

Background: The development of doppler ultrasonographic technology has provided an opportunity to obtain a qualitative and quantitative assessment of maternal and foetal circulation using a non-invasive method. It has been proved by many studies that doppler has a very important role in screening of high-risk pregnancies. Objective of this study was to evaluate the role of colour doppler study in normal and high-risk pregnancy in relation to perinatal outcome.

Methods: A prospective study was done including 75 women with high risk pregnancy and 75 normal pregnant women during the period October 2018 to September 2019 in hospitals attached to Bangalore Medical College and Research Institute. Doppler examination was done after recording patients' history, clinical examination and ultrasound. Results were analysed and conclusions were made.

Results: Out of the 22 patients with PIH, 20 patients had abnormal umbilical artery S/D ratio and all 22 had abnormal MCA PI. Out of 12 patients with diabetes, 10 had abnormal umbilical artery S/D ratio. All the patients with IUGR had abnormal umbilical artery S/D ratio and abnormal MCA PI.

Conclusions: Colour doppler flow velocimetry done repeatedly can predict adverse foetal events with a great degree of accuracy.

Keywords: Abnormal umbilical artery S/D ratio, Abnormal middle cerebral artery pulsatility index, High-risk pregnancy, Neonatal death

\section{INTRODUCTION}

The development of doppler ultrasonographic technology has provided an opportunity to obtain a qualitative and quantitative assessment of maternal and foetal circulation using a non-invasive method. ${ }^{1}$ It has been proved by many studies that doppler has a very important role in screening of high-risk pregnancies. ${ }^{2-4}$

It has been studied that doppler velocimetry of umbilical artery in unselected and low-risk pregnancies cannot be recommended. ${ }^{5}$ In contrast, it has been proved by many studies that doppler has a very important role in screening of high-risk pregnancies. ${ }^{6,7}$ The advantage of colour doppler flow velocimetry is the early diagnosis of IUGR which can reduce the foetal morbidity and mortality. ${ }^{8,9}$

\section{METHODS}

This is a prospective study for a period of one year from October 2018 to September 2019 in hospitals attached to Bangalore Medical College and Research Institute. 
Group A included 75 control subjects (normal pregnancies) and Group B included 75 pregnant women with high risk pregnancies. Doppler examination was done after recording patients' history, clinical examination and ultrasound.

\section{Inclusion criteria}

- Singleton pregnancy

- Gestational age of 26 weeks to term and are sure of their last menstrual period or had a dating scan in the 1st trimester

- Pregnancy with high-risk factor with or without clinical evidence of growth retardation

- Clinical suspicion of IUGR.

\section{Exclusion criteria}

- Multiple pregnancies.

Total 150 were selected with purposive sampling technique with (75 cases) study group of high-risk pregnancy taken into the study and compared with an equal number of women with normal pregnancy without complication (control group).

\section{Statistical analysis}

The following methods of statistical analysis have been used in this study.

SPSS version 16 were used for data entry and analysis.

- Student's t-test

- Proportions were compared using Chi-square test of significance.

In all the above tests, the P-value of less than 0.001 was accepted as indicating statistical significance.

\section{RESULTS}

Table 1: Categorization of cases.

\begin{tabular}{|lll|}
\hline Risk factor & Number of patients & $\%$ \\
\hline APH & 7 & $9.33 \%$ \\
\hline PIH & 22 & $29.33 \%$ \\
\hline Diabetes & 12 & $16 \%$ \\
\hline Anaemia & 6 & $8 \%$ \\
\hline Rh negative & 3 & $4 \%$ \\
\hline IUGR & 5 & $6.67 \%$ \\
\hline PIH+IUGR & 8 & $10.67 \%$ \\
\hline Diabetes + IUGR & 3 & $4 \%$ \\
\hline Anaemia + IUGR & 4 & $5.33 \%$ \\
\hline Diabetes + PIH+ IUGR & 2 & $2.67 \%$ \\
\hline PIH +Anaemia + IUGR & 3 & $4 \%$ \\
\hline Total & $\mathbf{7 5}$ & $\mathbf{1 0 0 \%}$ \\
\hline
\end{tabular}

According to Table 1, the most common high risk in our study group was PIH (30.04\%\%) either alone (29.33\%) or in combination with other risk factor like IUGR and anaemia (13.33\%). The second most common high risk in our study group was IUGR $(22.04 \%)$ either alone $(6.67 \%)$ or in combination with other risk factors like $\mathrm{PIH}$, diabetes, anaemia (15.37\%). The least common was Rh negative pregnancy with 3 patients $(4 \%)$.

Table 2: Comparison of umbilical artery doppler indices.

\begin{tabular}{|llll|}
\hline $\begin{array}{l}\text { Umbilical } \\
\text { artery }\end{array}$ & $\begin{array}{l}\text { Study } \\
\text { group }\end{array}$ & $\begin{array}{l}\text { Control } \\
\text { group }\end{array}$ & P-value \\
\hline PI & $1.72 \pm 0.39$ & $0.87 \pm 0.21$ & $<0.001$ \\
\hline RI & $0.72 \pm 0.09$ & $0.57 \pm 0.07$ & $<0.001$ \\
\hline S/D & $3.78 \pm 0.78$ & $2.13 \pm 0.26$ & $<0.001$ \\
\hline
\end{tabular}

According to Table 2, PI, RI and S/D ratio of the umbilical artery were significantly higher in the study group $(1.72,0.72,3.78)$ than the control group $(0.87$, $0.57,2.13)$. This indicates that doppler changes are more in the study group comprising of high-risk pregnancy.

Table 3: Comparison of middle cerebral artery indices.

\begin{tabular}{|llll|}
\hline $\begin{array}{l}\text { Middle } \\
\text { cerebral artery }\end{array}$ & $\begin{array}{l}\text { Study } \\
\text { group }\end{array}$ & $\begin{array}{l}\text { Control } \\
\text { group }\end{array}$ & P-value \\
\hline PI & $1.06 \pm 0.24$ & $1.29 \pm 0.21$ & $<0.001$ \\
\hline RI & $0.65 \pm 0.05$ & $0.73 \pm 0.18$ & $<0.001$ \\
\hline S/D & $3.01 \pm 1.02$ & $3.95 \pm 0.92$ & $<0.001$ \\
\hline
\end{tabular}

According to Table 3, PI, RI AND S/D ratio of MCA in high risk pregnancy group $(1.06,0.65,3.01)$ were significantly lower than the control group. This indicates that high risk pregnancy is more associated with brain sparing effect in the foetus.

According to Table 4, out of the 22 patients with PIH, 20 patients had abnormal umbilical artery S/D ratio and all 22 had abnormal MCA PI. Among these, 15 neonates had low Apgar and 2 neonates were low birth weight, 7 neonates needed NICU admission and there was 1 neonatal death. Out of 12 patients with diabetes, 10 had abnormal umbilical artery S/D ratio and 9 neonates had low Apgar and 1 neonate had low birth weight and 3 neonates needed NICU admission. All the patients with IUGR had abnormal umbilical artery S/D ratio and abnormal MCA PI. There was 1 neonatal death in a patient with diabetes with PIH and IUGR.

According to Table 5, majority of patients had LSCS $(72 \%)$ in the study group and in control group most of them had normal vaginal delivery. ${ }^{7}$ preterm delivery was seen in study group. This indicates that there is a higher caesarean delivery rate in high risk pregnancy compared to normal pregnancy. The incidence of preterm delivery is higher in high risk pregnancy. 
Table 4: Doppler in different categories of patient.

\begin{tabular}{|llllllll|}
\hline Risk factor & $\begin{array}{l}\text { Number of } \\
\text { patients }\end{array}$ & $\begin{array}{l}\text { Umbilical } \\
\text { artery S/D } \\
\mathbf{7}\end{array}$ & $\begin{array}{l}\text { Abnormal } \\
\text { MCA PI }\end{array}$ & $\begin{array}{l}\text { Low Apgar } \\
(<\mathbf{7})\end{array}$ & $\begin{array}{l}\text { Low birth } \\
\text { weight } \\
\mathbf{2 . 5} \text { kg }\end{array}$ & $\begin{array}{l}\text { NICU } \\
\text { admission }\end{array}$ & $\begin{array}{l}\text { Neonatal } \\
\text { death }\end{array}$ \\
\hline APH & 7 & 5 & 0 & 5 & 2 & 0 & 0 \\
\hline PIH & 22 & 20 & 22 & 15 & 2 & 7 & 1 \\
\hline Diabetes & 12 & 10 & 0 & 9 & 1 & 3 & 0 \\
\hline anaemia & 6 & 4 & 0 & 1 & 0 & 0 & 0 \\
\hline Rh negative & 3 & 2 & 0 & 1 & 0 & 0 & 0 \\
\hline IUGR & 5 & 5 & 5 & 4 & 2 & 2 & 0 \\
\hline PIH+IUGR & 8 & 8 & 8 & 7 & 7 & 7 & 1 \\
\hline Diabetes+ IUGR & 3 & 3 & 3 & 3 & 2 & 2 & 0 \\
\hline anaemia+ IUGR & 4 & 4 & 4 & 2 & 4 & 1 & 0 \\
\hline Diabetes+ PIH+ IUGR & 2 & 2 & 2 & 2 & 2 & 1 & 1 \\
\hline PIH+ anaemia+ IUGR & 3 & 3 & 3 & 3 & 3 & 1 & 0 \\
\hline Total & $\mathbf{7 5}$ & $\mathbf{6 6}(\mathbf{8 8 \% )}$ & $\mathbf{4 7}(\mathbf{6 2 . 6 7 \% )}$ & $\mathbf{5 2}$ & $\mathbf{2 5}$ & $\mathbf{2 4}$ & $\mathbf{3}$ \\
\hline
\end{tabular}

Table 5: Mode of delivery in study and control group.

\begin{tabular}{|lll|}
\hline Mode of delivery & Study group & Control group \\
\hline NVD & $14(18.67 \%)$ & $61(81.33 \%)$ \\
\hline LSCS & $54(72 \%)$ & $14(18.67 \%)$ \\
\hline PTVD & $7(9.33 \%)$ & - \\
\hline Total & $\mathbf{7 5 ( 1 0 0 \% )}$ & $\mathbf{7 5}(\mathbf{1 0 0 \%})$ \\
\hline
\end{tabular}

\section{DISCUSSION}

In a study by Bansal A et al, the most common high risk group in the study group was PIH (38\%) and the second most common high risk group was IUGR (18\%) which was similar to our study where the most common high risk was PIH (30.04\%) followed by IUGR..$^{10}$ In a study by Aparna G, $90 \%$ of all risk patients were diagnosed as preeclampsia $6 \%$ were gestational diabetes and $4 \%$ were PIH with IUGR. ${ }^{11}$

In current study PI, RI and S/D ratio of the umbilical artery were significantly higher in the study group than the control group. PI, RI and S/D ratio of MCA in high risk pregnancy group were significantly lower than the control group. All the patient with IUGR had abnormal umbilical artery S/D ratio and abnormal MCA PI. In a study by Mikovic et al, neonatal mortality $8.6 \%$, where as in current study neonatal mortality was $4 \%$ in high risk group. $^{12}$

In Shah D et al study, out of 43 IUGR cases, 38 cases, i.e., $88 \%$ of cases had abnormal Doppler findings. 16 cases, i.e., $37 \%$ cases among IUGR fetuses were IUD. ${ }^{13}$ In our study out of 25 IUGR case, all the case had abnormal doppler findings and 2 cases i.e $8 \%$ were neonatal death.

\section{CONCLUSION}

Colour doppler flow velocimetry done repeatedly can predict adverse foetal events with a great degree of accuracy. Doppler studies in high risk pregnancies are more beneficial in the management of good perinatal and neonatal outcomes.

Funding: No funding sources

Conflict of interest: None declared

Ethical approval: The study was approved by the Institutional Ethics Committee

\section{REFERENCES}

1. Low JA. The current status of maternal and fetal blood flow velocimetry. Am J Obstet Gynecol. 1991;164(4):1049-63.

2. Reed KL. Doppler-the fetal circulation. Clin Obstet Gynecol. 1997;40(4):750-4.

3. Hanretty KP, Primrose MH, Neilson JP, Whittle MJ. Pregnancy screening by doppler uteroplacental and umbilical artery waveforms. Br J Obstet Gynaecol. 1989;96(10):1163-7.

4. Pattinson RC, Norman K, Odendaal HJ. The role of Doppler velocimetry in the management of high-risk pregnancies. Br J Obstet Gynaecol. 1994;101(2):11420.

5. Goffinet F, Paris-Llado J, Nisand I, Breart G. Umbilical artery doppler velocimetry in unselected and low risk pregnancies: a review of randomised controlled trials. $\mathrm{Br} \mathrm{J}$ Obstet Gynaecol. 1997;104(4):425-30.

6. Reed KL. Doppler-the fetal circulation. Clin Obstet Gynecol. 1997;40(4):750-4.

7. Hanretty KP, Primrose MH, Neilson JP, Whittle MJ. Pregnancy screening by doppler uteroplacental and umbilical artery waveforms. Br J Obstet Gynaecol. 1989;96(10):1163-7.

8. Campbell S, Griffin D, Pearce JM. New Doppler technique for assessing uteroplacental blood flow. Lancet. 1983;1:675-7.

9. Trudiger BJ, Giles WB, Cook CM, Bom- bardieri J, Collins L. Fetal umbilical artery flow velocity 
waveforms and placental resistance: clinical significance. Br J Obstet Gynecol. 1985;92:23-30.

10. Bansal A, Choudhary J, Gupta H. Role of Panvessel doppler study in high risk pregnancy. IOSR-JDMS. 2015;14(2):90-3.

11. Aparna G, Suvarna V. A study of colour doppler in high risk pregnancies. Int $\mathrm{J}$ Contemporary Med Res. 2018;5(4):D13-D17.

12. Mikovic Z, Mandic V, Djukic M. Longitudinal analysis of arterial doppler parameters in growth retarded fetuses. Srp Arh Celok Lek. 2003;131:21-5.
13. Shah D, Shah C, Shastri M, Desai E, Patel D, Chitara M. A prospective study of role of color Doppler in high-risk pregnancies in a tertiary care hospital. Int $\mathbf{J}$ Med Sci Pub Health. 2017;6(8):1330-5.

Cite this article as: Chaithra M, Anitha GS, Suresh $\mathrm{S}$, Savitha C. A prospective study of role of doppler in pregnancy and the perinatal outcome. Int J Reprod Contracept Obstet Gynecol 2020;9:692-5. 